Agata Celińska-Miszczuk*

Lublin

Lidia Anna Wiśniewska**

Toruń

\title{
Komunikacja w rodzinie: od interakcji do osobowej relacji (perspektywa personalistyczna)
}

Komunikacja między ludźmi wydaje się zagadnieniem wyjątkowo prostym - komunikujemy się przecież codziennie. Rozmawiamy z bliskimi, słuchamy wiadomości, pytamy o godzinę czy drogę. Okazuje się jednak, że to pozorna prostota. Zjawisko komunikacji jest zagadnieniem złożonym. $\mathrm{Z}$ naukowego punktu widzenia można mówić o wielu jej aspektach, rodzajach, sposobach, modelach, o jej błędach i barierach ${ }^{1}$. W ramach pespektyw badawczych nad komunikacją analizuje się jej wpływ na jakość relacji pomiędzy ludźmi. Szczególne znaczenie ma analiza znaczenia komunikacji dla funkcjonowania rodziny. Szanse, jakie może stworzyć dobra komunikacja dla dobrego funkcjonowania rodziny, są tak duże, że niektórzy badacze uznają rodzinę za „system komunikacyjny”, zaś terapie rodzinne często koncentrują się przede wszystkim na poprawie procesu komunikowania między członkami rodziny (zwłaszcza między małżonkami²), gdyż przyjmuje się,

* Dr Agata Celińska-Miszczuk jest asystentem w Katedrze Psychologii Ogólnej Instytutu Psychologii KUL w Lublinie.

** Dr Lidia Wiśniewska jest adiunktem w Katedrze Psychologii na Wydziale Nauk Pedagogicznych UMK w Toruniu.

${ }^{1}$ Por. S. P. Morreale, B. H. Spitzberg, J. K. Barge, Komunikacja między ludźmi: motywacja, wiedza i umiejętności, Warszawa 2008; por. L. Grzesiuk, E. Trzebińska, Jak ludzie porozumiewaja się, Warszawa 1978.

${ }^{2}$ H. Goldenberg, I. Goldenbers, Terapia rodzin, Kraków 2006, s. 178-181. 
że ich sposób komunikowania z dużym prawdopodobieństwem modeluje komunikację w całym systemie rodzinnym ${ }^{3}$. Istnieje także wiele badań, które ujawniaja, że zadowolenie z małżeństwa jest powiązane właśnie $\mathrm{z}$ dobrą komunikacją ${ }^{4}$.

Komunikacja w rodzinach często jest jednak tylko komunikacją pozorną, ,zagadywaniem” ciszy. Jej pozorność (a tym samym utracenie jej twórczego potencjału) może być związana z podejmowanymi tematami. Często są one ogólne, niebudzące emocji, o których „bezpiecznie” można rozmawiać. Nie porusza się tematów ważnych, zwłaszcza trudnych. W relacjach pomiędzy ludźmi bliskimi nie temat - jako swoisty „czynnik zewnętrzny” - wyznacza jakość procesu komunikacji. Większe znaczenie ma dojrzałość osób zaangażowanych w ten proces. To ona (lub jej brak) wyznacza ich wzajemne, ujawniane również w komunikacji (w różnych sytuacjach, przy podejmowaniu różnorodnych tematów) ustosunkowanie do różnych spraw.

B. Harwas-Napierała ${ }^{5}$ - analizując komunikację interpersonalną w rodzinie na tle różnych sposobów jej ujmowania - wskazuje, że badacze podejmujący tą problematykę zajmują się z reguły dwoma jej aspektami: (1). analizują strukturę i/lub przebieg procesu komunikacji, konstruując różne jego modele lub (2). koncentrują się na wptywie procesu komunikacji na funkcjonowanie człowieka (w tym rodziny). Celem tego artykułu jest zaprezentowanie podstawowych zagadnień związanych z komunikacją w rodzinie z nieco odmiennej perspektywy: z perspektywy podmiotu - charakterologicznej dojrzałości członków rodziny, wyznaczającej ich względnie stały sposób ustosunkowania do siebie, który - wyrażając się w działaniu - będzie określał również sposób ich wzajemnej komunikacji. Inspiracją tych analiz jest zaproponowana przez W. Sterna (promotora personalistycznej orientacji w psychologii) charakterologiczna koncepcja działania człowieka (osoby), dookreślonego z perspektywy realizacji celów życiowo znaczących (wartości).

\section{Charakter czlowieka podstawą jakości jego relacji ze światem}

W. Stern, twórca koncepcji człowieka - osoby (,żyjącej całości”) - a zatem konkretnej jednostki ludzkiej, istniejącej i działającej w konkretnej sytus. $8-9$.

${ }^{3}$ Por. B. Harwas-Napierała, Komunikacja interpersonalna w rodzinie, Poznań 2008,

${ }^{4}$ M. Weryszko, Wplyw komunikacji w narzeczeństwie na zadowolenie z matżeństwa, w: W. Muszyński (red.), Wartości w rodzinie: ciagłość i zmiana, Toruń 2010, s. 131-141.

${ }^{5}$ B. Harwas-Napierała, dz. cyt., s. 13. 
acji życiowej (możliwości i ograniczeń), podkreśla, że charakter człowieka kształtuje się i ujawnia w bezpośrednich, wyrażanych w działaniu relacjach ze światem. Wyodrębniając w ramach wpływów świata wpływy świata natury, świata kultury i świata innych ludzi (krewnych, przyjaciół a nawet wrogów), tym ostatnim uwarunkowaniom przypisał decydujące znaczenie dla kształtowania naszego charakteru 6 .

Na podstawie obserwacji procesu rozwoju człowieka w jego naturalnym przebiegu W. Stern stwierdził, że działanie osoby ukierunkowane jest na realizację celów, które są znaczące życiowo, gdyż umożliwiają urzeczywistnienie idealnego celu istnienia i działania, właściwego jedynie człowiekowi: osobowości. Realizowane one są w działaniu podmiotowym, wyrażającym ustosunkowanie osoby do świata. W tym kontekście realizacja tych celów decyduje o kształtowaniu charakteru człowieka - jego niepowtarzalnej integralności. Na podstawie obserwacji i drobiazgowych analiz procesu rozwoju człowieka W. Stern dookreślił mniej lub bardziej dojrzałe sposoby ustosunkowania człowieka do swojego otoczenia ${ }^{7}$.

W. Stern stwierdził mianowicie, że naturalna dla człowieka, zwłaszcza na wczesnych etapach rozwoju (lub w nowych, nieznanych sytuacjach), jest realizacja celu samozachowania - urzeczywistnianego w formie dążenia do zabezpieczania siebie (swojego istnienia, własnej odrębności fizycznej i psychicznej) i przystosowania do zewnętrznych uwarunkowań. Wprawdzie dążenie samozachowawcze jest niezbędnym warunkiem rozwoju (utrwalenie wewnętrznej integralności osoby warunkuje mianowicie jej otwartość na zmiany), jednak urzeczywistnia się w działaniu w dużej mierze w formie reaktywnych sposobów funkcjonowania i wyraża negatywne ustosunkowanie do otaczającej rzeczywistości (w tym do innych ludzi). Świat, inni ludzie traktowani są w tej sytuacji jako czynnik obcy czy nawet zagrażający osobie. Wyrazem tej formy działania jest ukierunkowanie na samoobronę $\mathrm{w}$ drodze unikania czy też przeciwdziałania obcym, zewnętrznym oddziaływaniom lub też reaktywne dopasowanie siebie do świata ${ }^{8}$. Inną, wprawdzie wyższą, jednak wciąż ograniczającą możliwości rozwoju człowieka, formą działania jest egocentryczna realizacja siebie, wyrażająca się w formie ekspresji sie-

${ }^{6}$ W. Stern, Person und Sache. System des kritischen Personalismus. Band 2: Die menschliche Persönlichkeit, Leipzig 1923, s. 106, 115-121; por. A. Celińska, Williama Sterna koncepcja krytycznego personalizmu, w: T. Rzepa (red.), Na ścieżkach historii psychologii, Szczecin 2003, s. 131-140.

7 W. Stern, Person und Sache, s. 18-54; tenże, Allgemeine Psychologie auf personalistischer Grundlage, Haag 1950, s. 609-613.

${ }^{8}$ Tenże, Person und Sache, s. 125-130; tenże, Allgemeine, s. 610-611; por. A. Celińska-Miszczuk, Williama Sterna personalistyczna perspektywa typologiczna, w: P. Francuz, W. Otrębski (red.), Studia z psychologii w KUL, t. 15, Lublin 2008, s. 11-26. 
bie, dążenia do wzrostu poczucia własnej wartości i siły na obszarze świata, traktowanego - jako czynnik zewnętrzny, obcy (czasem też zagrażający) przedmiotowo9.

W. Stern zaznacza, że żadna z powyższych form funkcjonowania nie jest zdeterminowana ani siłą wrodzonego procesu (np. wrodzonej cechy temperamentu), ani też siłą zewnętrznego oddziaływania. Style te wyrażają mianowicie kształtowany od wczesnego dzieciństwa (na podstawie indywidualnych doświadczeń) i - co ważne - wybrany przez osobę (która jest podmiotem działania) sposób jej ustosunkowania do świata. To człowiek (podmiot działania) nadaje negatywne znaczenie otaczającej rzeczywistości. Może być ono uzasadnione dotychczasowymi doświadczeniami, jednak koncentracja na nich, brak otwartości na obiektywność istniejącej poza nami rzeczywistości (która nie jest niezmienna), sprawia, że negatywne jej postrzeganie jest generalizowane na inne sytuacje.

Oba powyższe sposoby działania - wyrażając negatywne ustosunkowanie osoby do świata - decydują o specyficznej, wyrażanej w działaniu z nim relacji. Przypomina ona interakcję dwóch, niezależnych, obcych sobie (często nawet wrogich - jeśli stosunek jest odwzajemniony przez innych) rzeczywistości ${ }^{10}$ (por. rys. 1).

Uznanie świata za obcy czy też zagrażający nie neguje tego, jakim on obiektywnie jest. Dopóki jednak człowiek zamyka się w sobie, nie otwiera się na komunikaty płynące ze strony świata, pozostanie na poziomie reaktywnego, niedojrzałego sposobu działania, stanowiącego podstawę jedynie interakcyjnego oddziaływania obcych sobie czy nawet wrogich „elementów" tego „spotkania” (por. rys. 1). Przejawianie takiego sposobu funkcjonowania w uzasadnionych, konkretnych sytuacjach (kiedy np. inni faktycznie zagrażają) służy człowiekowi. Niekorzystne jest w sytuacji jego zgeneralizowania $\mathrm{i}$ utrwalenia $\mathrm{w}$ formie względnie stałego, ujawnianego w różnych sytuacjach stylu działania.

W. Stern - akcentując, że właściwe jedynie człowiekowi sposoby funkcjonowania mają charakter dyspozycyjny i dla ich rozwoju niezbędny jest kontakt osoby ze światem konwergentnym, odpowiadającym tym dyspozycjom - podkreśla, że jedynie otwartość na pełne i bezpośrednie relacje ze światem innych osób warunkuje możliwość pełnego rozwoju człowieka,

9 W. Stern, Person und Sache, s. 127-129; tenże, Allgemeine, s. 610-611; por. A. Celińska-Miszczuk, Williama Sterna, s. 11-26.

${ }^{10}$ W. Stern, Person und Sache, s. 122-124; tenże, Allgemeine, s. 124; por. A. Celińska-Miszczuk, Współdziałanie warunkiem wolności? Ujęcie W. Sterna (od modelu interakcyjnego do modelu ludzkiego działania), w: Z. B. Gaś (red.), Człowiek w obliczu zniewolenia. Od zagrożeń do nadziei, Lublin 2012, s. 220-221. 
jego osobowości. Najpełniejsza realizacja ludzkich możliwości następuje w relacji ze światem uznanym przez człowieka za jemu odpowiadający, odpowiadający jego dążeniom celowym, spójny z realizowanymi przez niego celami/wartościami. W sytuacji otwartości na obiektywną, jakościową odrębność świata człowiek nie traktuje go jako czynnika zagrażającego czy wrogiego, ale - z racji jego odmienności - jako istotny czynnik dopetniajacy: stawiający wyzwania i ograniczenia, ale jednocześnie (umożliwiając przekroczenie status quo) oferujący możliwości rozwoju ${ }^{11}$. Otwierając się na innych, człowiek doświadcza mianowicie tego, kim jest i jakim jest (własnej odrębności) w kontekście odrębności charakteryzującej świat (innych ludzi). Doświadczenie to może „wyzwolić” w człowieku pragnienie rozwoju, stawania się takim, jakimi są inni ludzie (o ile mu imponują, stanowią dla niego autorytet etc.).

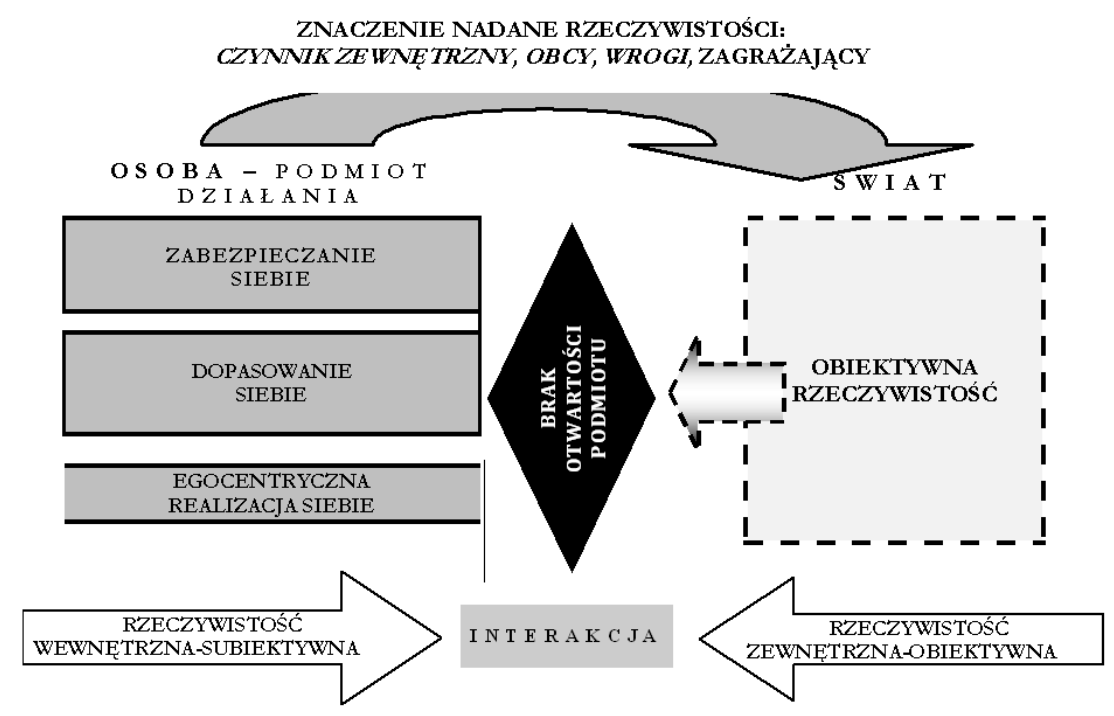

Rys. 1. Interakcja w działaniu osoby z perspektywy koncepcji W. Sterna (oprac. A. Celińska-Miszczuk na podstawie pism W. Sterna, Person und Sache. System des kritischen Personalismus, Leipzig 1923; tenże, Algemeine Psychologie auf personalistischer Grundlage, Haag 1950)

Dążenia powyższego nie można jednak utożsamić z niedojrzała, opisaną powyżej, tendencją dopasowania siebie do wymagań świata. Warunkiem pełnych, wzajemnych (dialogicznych) relacji, określanych przez W. Sterna

${ }^{11}$ W. Stern, Person und Sache, s. 114-127. 
terminem konwergencji ${ }^{12}$, jest mianowicie introcepcja ${ }^{13}$ oferowanych przez innych celów/wartości - proces przyjęcia ich w obręb celów/wartości własnych, ich upodmiotowienie (uczynienie własnymi ${ }^{14}$ ). Konwergencja jest zatem wzajemną, dialogiczną relacją dwóch osób (podmiotów dzialania), które z racji swojej odmienności stwarzają sobie wzajemnie szansę rozwoju, gdyż - jak pisze W. Stern ${ }^{15}$ - w konwergentnej relacji ,jedna osoba jako indywidualność dostarcza drugiej osobie - indywidualności niepowtarzalnych strun do wybrzmienia tej indywidualności”.

Osoba w konwergentnej relacji ( $\mathrm{w}$ przeciwieństwie do interakcyjnej) jako podmiot działania jest podmiotem poszukujacym możliwości rozwoju (nie jedynie wykorzystującym manipulacyjnie innych) lub też podmiotem odpowiadajacym na wyzwania otaczającego świata (nie zaś chroniącym siebie przed nimi). Nie neguje zatem podmiotowości drugiej strony tego dialogicznego spotkania (por. rys. 2).

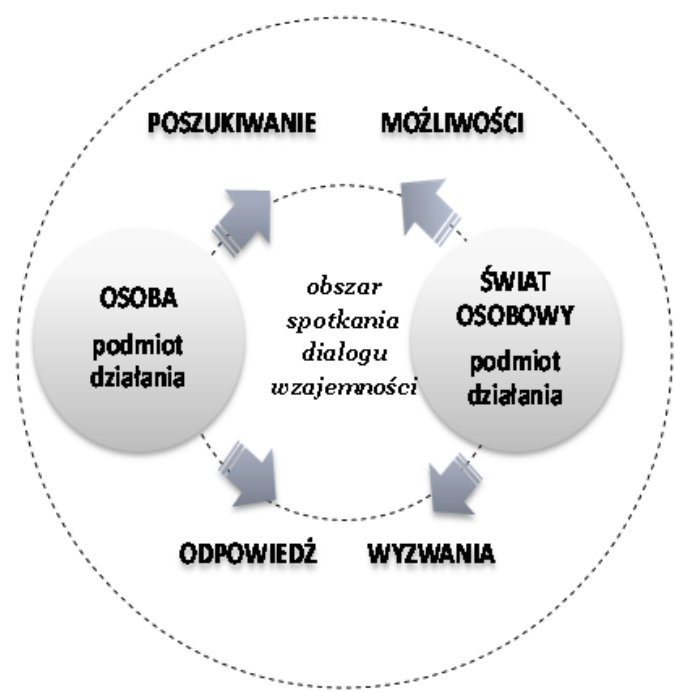

Rys. 2. Osobowa relacja z perspektywy koncepcji Sterna (oprac. A. Celińska-Miszczuk na podstawie pism W. Sterna)

Przyjęcie konwergencji (otwartości na dialogiczne relacje, na współdziałanie z innymi osobami) jako podstawy rozwoju człowieka nie oznacza,

12 Tamże, s. 10.

13 Tamże, s. 58.

${ }^{14}$ Por. A. Celińska-Miszczuk, Współdziałanie warunkiem, s. 225-229.

15 W. Stern, Person und Sache, s. 119. 
że dojrzała osoba nie powinna ujawniać opisanych powyżej (zabezpieczających czy też ekspresywnych) sposobów działania. Wręcz przeciwnie. Istotny jest fakt, że u dojrzałej osoby dominująca i względnie trwała jest jej orientacja na współdziałanie z innymi oraz towarzysząca temu jej zdolność elastycznego dopasowania swojego działania do wymagań konkretnej (obiektywnej) sytuacji ${ }^{16}$. O ile mamy do czynienia $\mathrm{z}$ otwartością drugiej strony na dojrzały sposób nawiązywania kontaktu, będzie to dialogiczne spotkanie dwóch osób - dwóch podmiotów działania, nie zaś interakcja dwóch niezależnych, obcych sobie (czy nawet wrogich) „elementów” spotkania.

\section{Komunikacja werbalna i niewerbalna w osobowej relacji}

Trudno jednoznacznie zdefiniować komunikację interpersonalną. W literaturze psychologicznej dominują dwa ujęcia tego procesu. Ujęcie węższe identyfikuje ten proces z przekazywaniem informacji między jego podmiotami (partnerami interakcji, nadawcą i odbiorca). W ujęciu szerszym natomiast nacisk położony jest na znaczenie tego procesu w relacjach społecznych, na jego dynamikę ${ }^{17}$. Ta dynamika jest szczególnie ważna w przypadku rodziny $-\mathrm{z}$ jednej strony komunikacja $\mathrm{w}$ systemie rodzinnym nieustannie się zmienia, jest procesem aktywnym, dynamicznym, z drugiej - każdy komunikat zmienia i jego nadawcę, i jego odbiorcę ${ }^{18}$. Nie można tutaj więc mówić o związku przyczynowo-skutkowym, ani o sprzężeniu zwrotnym (choć takie ujęcie pojawia się w literaturze $)^{19}$. Z perspektywy W. Sterna należy powiedzieć o wzajemnym wpływaniu jednej osoby na drugą. Każdy komunikat, jako przejaw działania osoby, wywołuje konkretną odpowiedź drugiej strony tej relacji - czy to w postaci przekazu słownego, czy też pozasłownego.

${ }^{16}$ Należy jednak pamiętać, że druga osoba nie zawsze będzie stwarzała warunki do nawiązywania dialogicznej relacji, np. jeśli wyraża tendencje manipulacyjne; w takiej sytuacji adekwatne będzie działanie skoncentrowane na zabezpieczaniu siebie; będzie to sposób działania dostosowany do wymagań konkretnej sytuacji, nie zaś względnie stały (charakteryzujący osobę) styl jej działania.

${ }_{17}$ B. Harwas-Napierała, dz. cyt., s. 13-14.

${ }_{18}$ U. Gruca-Miąsik, Komunikacja interpersonalna $w$ rodzinach zastępczych - ujęcie systemowe, w: B. Aouil, W. J. Maliszewski (red.), Media - komunikacja: zdrowie i psychologia, Torun 2007, s. 302-303.

19 A. Chybicka, K. Karasiewicz, Zadowolenie z intymnych relacji oraz poczucie własnej atrakcyjności i komunikacji w zwiazkach narzeczeńskich i matżeńskich, w: T. Rostowska (red.), Psychologia rodziny. Matżeństwo i rodzina wobec wspótczesnych wyzwań, Warszawa 2009, s. 138. 
Wydaje się wprawdzie, że komunikacja to przede wszystkim słowo ${ }^{20}$, ale w komunikacji pełni ono jedynie rolę cząstkową - komunikacja nie zamyka się jedynie w słowie. To wprawdzie słowo niesie ze sobą jakiś (mniej lub bardziej jasny przekaz), nazywa $\cos ^{21}$, ale jednocześnie jest wypowiadane w określony sposób. Ton głosu, jego intonacja, barwa, wysokość, tempo mówienia, akcent czy intonacja oraz różne gesty, wyraz twarzy czy kontakt wzrokowy - to wszystko też jest ważne.

Komunikacja pozawerbalna może być wieloznaczna - na przykład gest trzymania rąk w kieszeni jedni mogą odbierać jako obraźliwy, lekceważący, a inni jako przejaw nieskrępowania czy dobrego samopoczucia, a przez to jest zależna od kontekstu bardziej niż słowo ${ }^{22}$. Komunikaty te zazwyczaj występują w postaci pewnej sekwencji (np. uśmiech). Przyjmuje się, że są też bardziej szczere, gdyż trudniej mieć nad nimi kontrolę i je zafałszować23. Zależność od kontekstu oraz wieloznaczność mogą prowadzić do nieporozumień. Osoba, która ma postawę obronną, może wybierać te interpretacje, które będą podtrzymywać jej wizję świata - nawet w sytuacji, w której inna interpretacja byłaby bardziej prawdopodobna.

Coraz częściej podkreśla się, że w komunikacji nie powinno wyróżniać się żadnego z jej typów jako decydującego czy dominującego o jej jakości. Ważna jest za to spójność komunikacji ${ }^{24}$, co oznacza, że aspekt pozasłowny powinien być koherentny ze słowem. Spójność działania jest kluczowym wyrazem dojrzałego funkcjonowania w ujęciu W. Sterna. Brak spójności w komunikatach często prowadzi do konfliktów. W małżeństwie, obok zapewnień o wzajemnej miłości czy szacunku, powinny pojawiać się takie gesty jak przytulanie, pocałunki czy kwiaty ${ }^{25}$. Także w rozmowach z dziećmi ważne jest, aby ton głosu i sposób ekspresji podkreślał głoszoną dumę czy zadowolenie. Okazuje się, że niespójne przekazy o miłości (tzn. takie, w których miłość nie jest okazywana w żaden inny sposób) wraz z tak zwanymi pustymi przekazami (mówiącymi jak bardzo dziecko jest wspaniałe, nawet jeśli jego zachowanie o tym nie świadczy) mogą być dla dziecka niezwykle

20 S. P. Morreale, B. H. Spitzberg, J. K. Barge, dz. cyt., s. 141-161; P. Nowak, O mówieniu tego, co sie chce $i$ jak sie chce, czyli komunikacja językowa w sztuce mediacji, w: A. Lewicka (red.). Profesjonalny mediator - zostań nim. Poradnik metodyczny, Lublin 2008, s. 143-160.

${ }^{21}$ J. Stewart, C. Logan, Komunikowanie się werbalne, w: J. Stewart (red.), Mosty zamiast murów. Podręcznik komunikacji interpersonalnej, Warszawa 2008, s. 80-102.

${ }^{22}$ S. P. Morreale, B. H. Spitzberg, J. K. Barge, dz. cyt., s. 175-176.

${ }^{23}$ T. G. Grove, Niewerbalne elementy interakcji, w: J. Stewart (red.), dz. cyt., s. $125-$ -126 .

${ }^{24}$ Por. S. Chełpa, T. Witkowski, Psychologia konfliktów, Wrocław 2004, s. 44.

25 Por. M. Braun-Gałkowska, Psychologia domowa, Lublin 2005. 
krzywdzące. Takie komunikaty powodują, że dzieci stają się bardziej pasywne, mają trudności z docenieniem własnego sukcesu - a przede wszystkim w powiązaniu sukcesu $\mathrm{z}$ wysiłkiem $\mathrm{w}$ niego włożonym. Stają się też mniej wytrwałe w swoich działaniach, bardziej znudzone, depresyjne i mniej zmotywowane do działania ${ }^{26}$. Spójność komunikatu wymaga jednak szczerości wobec samego siebie i innych - nie zaś obronnego nastawienia. Tylko w takim wypadku komunikacja będzie dialogiem, a nie jedynie interakcją $\mathrm{z}$ drugą osobą.

Komunikacja w rodzinach nie powinna zawierać tematów tabu - przynajmniej między osobami z najbliższego kręgu rodzinnego. Jednak w rodzinach, także między małżonkami, bardzo często istnieją tematy, o których się nie mówi, których się nie porusza, które są jakby zakazane. Zazwyczaj dotyczą one spraw trudnych, wstydliwych, nieprzyjemnych ${ }^{27}$.

Wyrazem interakcji w rodzinie, ale nie dialogu z drugą osobą, są wspomniane powyżej błędy, u podstaw których można poszukiwać braku otwartości osoby na innych, braku poczucia bezpieczeństwa, braku zaufania do innych, często też braku zaufania do siebie. Podsumowując, są one następujące: (1). brak spójności pomiędzy komunikatami werbalnymi i pozawerbalnymi (2). unikanie poruszania pewnych tematów (zwłaszcza trudnych, często ważnych).

\section{Częste bariery osobowego kontaktu i sposoby ich pokonywania}

Także zaktadanie przez odbiorce, że wie, co chce powiedzieć nadawca, wpisuje się w ten rodzaj komunikacji - interakcyjnej, niedialogicznej. Można wyobrazić sobie sytuację, w której kilka osób ma narysować rysunek na dany temat (np. drzewo czy kwiat). Istnieje wysokie prawdopodobieństwo, że każda z nich narysuje coś innego. Ludzie mają bowiem różne wyobrażenia drzew czy kwiatów. Wydaje się to oczywiste. Jednak bardzo często pojawia się w tej sytuacji błąd zakładania tego, co „powinien” narysować partner. W ten sposób zakłada się, że inni mają taki sam obraz świata ${ }^{28}$. Osoba o obronnej orientacji - w sytuacji niespełnienia swojego oczekiwania, otrzymania komunikatu innego, niż oczekiwany (a zatem innego, niż tożsamy z jej przekonaniem) - może postrzegać innych jako potencjalnych agre-

${ }^{26}$ C. Segrin, J. Flora, Family Communication, New York 2011, s. 144-146.

${ }^{27}$ L. Grzesiuk, E. Trzebińska, dz. cyt., s. 63-68.

${ }^{28}$ J. Stewart, M. Thomas, Stuchanie dialogiczne: lepienie wzajemnych znaczeń, w: J. Stewart (red.), dz. cyt., s. 235; S. P. Morreale, B. H. Spitzberg, J. K. Barge, dz. cyt., s. $144-147$. 
sorów, nastawionych do świata podobnie wrogo jako ona. Fakt niespełnienia mojego wyobrażania o tym, co myślą inni czy też co „powinni” myśleć i przekazywać nam inni, nie czyni ich naszymi wrogami. Odmienność, jak zaznaczono powyżej, nie oznacza przeciwstawności ${ }^{29}$.

Błąd ten często dotyczy istotnych kwestii w rodzinie. Szczególnie dużo nieporozumień $\mathrm{w}$ tym względzie jest związanych $\mathrm{z}$ takimi słowami jak miłość, wsparcie, rodzina, a nawet wierność, uczciwość czy pracowitość. $\mathrm{Z}$ jednej strony, wydają się być one zrozumiałe, ale z drugiej - ich szeroki zakres pozwala, aby każdy nadawał im własne znaczenie ${ }^{30}$. Prowadzi to do nieporozumień. Często małżonkowie zarzucają sobie nawzajem, że nie kochają się czy nie wspierają. Nie zawsze jest to prawdą. Dla żony wsparcie może oznaczać wsparcie emocjonalne - rozmawianie o trudnościach, dzielenie się przeżyciami i inne czynności, które mają pomóc jej w uporaniu się z emocjami. Z kolei dla męża najlepszym wsparciem może być zostawienie go w spokoju czy pozwolenie na to, aby zajął się konkretnym działaniem. Warto otworzyć się na odmienność drugiego człowieka, na właściwe mu potrzeby, jego system wartości, które ujawniane są w indywidualnym sposobie komunikacji. Przed przystąpieniem do rozmowy powinno się akceptować drugą osobę. Ta akceptacja wynika między innymi z godności przypisanej osobie ludzkiej i należnego jej szacunku. Oznacza ona, że osoba jest ważna. Akceptacja nie jest jednoznaczna $\mathrm{z}$ aprobatą tego, co osoba robi. Ale daje osobie prawo do mówienia o sobie, nawet o swoich błędach, bez obawy o bycie oceniana, wyśmianą czy odrzuconą. Buduje zaufanie, które umożliwia mówienie o sobie i o swoim życiu ${ }^{31}$.

Podobne sytuacje związane z brakiem zrozumienia drugiej osoby mogą mieć miejsce bardzo często i dotyczą wielu różnych spraw. Są one nasilane przez to, że partnerzy kontaktu nie są przyzwyczajeni do dookreŚlania (klaryfikacji) tego, co druga strona chce/chciała przekazać. W sytuacji obronnego nastawienia pytania, takie jak „,co masz na myśli”, „,czy mógłbyś/ mogłabyś to wyjaśnić", są często traktowane jako atakujące, nam zagrażające. Zaufania do siebie i innych, otwartości na siebie i innych wymaga również przyznanie się do tego, że się czegoś nie rozumie.

W pokonaniu bariery zakładania tego, że wiem, co chce powiedzieć mi rozmówca, pomocne może być też tak zwane parafrazowanie - opisywanie meine.

${ }^{29}$ S. P. Morreale, B. H. Spitzberg, J. K. Barge, dz. cyt., s. 144-147; W. Stern, Allge-

${ }^{30}$ J. Stewart, M. Thomas, dz. cyt., s. 238-252; S. P. Morreale, B. H. Spitzberg, J. K. Barge, dz. cyt., s. 144-147.

${ }^{31}$ Por. S. Geller, M. Król, Kontakt interpersonalny $w$ wywiadzie diagnostycznym, w: T. Szustrowa (red.), Swobodne techniki diagnostyczne. Wywiad i obserwacja, Warszawa 2005, s. 9-10; E. Sujak, ABC psychologii komunikacji, Kraków 2006, s. 21-25. 
innymi słowami (czasem też wyrażane w formie symbolicznej, np. rysunku dziecka) znaczenia tego, co chce się powiedzieć ${ }^{32}$. W sytuacji obronnego nastawienia rzadko ta forma wyjaśnienia zostanie wykorzystana. Opisane umiejętności, takie jak parafrazowanie czy klaryfikacja (obok szeregu innych), są niezbędne zarówno $\mathrm{w}$ profesjonalnych relacjach (m.in. psychologicznych czy terapeutycznych) ${ }^{33}$, jak również niezmiernie przydatne w codziennym życiu. Wymagają jednak przekroczenia perspektywy własnej i otwartości na drugiego człowieka, zaangażowania $\mathrm{w}$ dialog z drugą osobą ${ }^{34}$. Otwartość, zaufanie, poszanowanie indywidualności drugiego człowieka (również tego, że może mieć chwilowo zły nastrój), a zatem empatia i transparentność (rozumiana jako m.in. koherentność) są podstawowymi wyznacznikami dobrej komunikacji w rodzinie ${ }^{35}$.

\section{Konflikt i spór w rodzinie - podstawa osobowego kontaktu czy jego unicestwienie}

Jak zauważono wcześniej, brak dobrej komunikacji (tj. brak kontaktu osobowego, nawet przy istnieniu komunikacji interakcyjnej) prowadzi często do konfliktów. Niektóre czynniki, które prowadzą do konfliktu (tzw. detektory), są właśnie związane z nieprawidłową komunikacją ${ }^{36}$. Dotyczą one między innymi unikania bezpośredniej komunikacji i nadmiernej jej formalizacji. Zdarza się więc, że - w sytuacji ograniczenia czy w szczególności zaniku otwartości na drugiego człowieka - członkowie rodziny, zamiast rozmawiać, komunikują się przez kartki, wiadomości tekstowe lub drogą mailową. Pośredni sposób kontaktu staje się podstawowym sposobem porozumiewania się.

Kolejna trudność w komunikacji w rodzinie jest związana z tym, że osoby nie są w stanie podjąć dialogu, ale uparcie bronią swojego zdania - nawet jeśli wiedzą, że nie mają całkowitej racji. W sytuacji istniejącego konfliktu szczególnie negatywnie na możliwości jego rozwiązania wpływają dwa typy komunikatów: unikajace tematu konfliktu oraz go podtrzymujace ${ }^{37}$. Do pierwszej grupy można zaliczyć takie zachowania, jak zaprzeczanie istnieniu trudności czy zniechęcanie do jego rozwiązania. Z kolei podtrzymywanie

\footnotetext{
32 J. Stewart, M. Thomas, dz. cyt., s. 247-249.

${ }_{33}$ Por. B. F. Okun, Skuteczna pomoc psychologiczna, Warszawa 2002, s. 82-85.

${ }^{34}$ J. Stewart, M. Thomas dz. cyt., s. 235.

${ }^{35}$ A. Chybicka, K. Karasiewicz, dz. cyt., s. 138-139.

${ }^{36}$ S. Chełpa, T. Witkowski, dz. cyt., s. 150-151.

37 Tamże.
} 
konfliktu może odbywać się poprzez wzajemne pretensje, obwinianie czy nakazy, groźby, a nawet szantaż emocjonalny. Oprócz takich jawnych działań mogą pojawić zachowania mniej transparentne - obejmujące wrogie pytania czy złośliwe żarty. Należy jednocześnie pamiętać, że bardzo często dodatkowo wszystkie wypowiedzi są silnie nacechowane emocjonalnie - a działając pod wpływem emocji, osoba nie jest w stanie wziąć pod uwagę racjonalnych argumentów. Ponadto, konflikt często wyzwala lawinę wzajemnych pretensji, które dotyczą wielu różnych spraw, niekoniecznie związanych z obecną $\operatorname{sytuacja}^{38}$. Jego rozwiązanie wymaga zaś wyjścia poza zachowania obronne i skupienia się na relacji z drugą osobą, a nie na samym sobie.

Na podstawie powyższych, typowych przykładów błędów w komunikacji wyzwalających konflikt można dojść do przekonania, że dla prawidłowego funkcjonowania rodziny niezbędne są rozmowy nie tylko częste, ale takie, które powinny sprawiać przyjemność. Błędnym jest jednak przekonanie, że jest to podstawą osobowego kontaktu (dialogicznej relacji). Brak jakichkolwiek sporów może być również wyznacznikiem interakcji. Osoby uczą się bowiem, których tematów unikać, aby nie wywołać sporu. Zamiast więc rozmawiać - jedynie wchodzą ze sobą w mniej lub bardziej przypadkowe interakcje.

Jak podkreślono wcześniej, W. Stern - akcentując znaczenie otwartości na drugiego człowieka - przyjmował, że niezbędnym jej warunkiem jest introcepcja (przyjęcie za własne, upodmiotowienie) oferowanych przez świat, w szczególności innych ludzi, celów/wartości. Nie odbywa się to automatycznie. Z racji jakościowej odmienności świata, w szczególności innych ludzi, często procesowi temu, co w sposób szczególny podkreślał W. Stern ${ }^{39}$ w swoim ostatnim dziele, towarzyszą „,napięcia i sprzeczności”. Nie negują one możliwości osobowego kontaktu, przeciwnie - umożliwiają doświadczenie go w sposób autentyczny. Spory - komunikowane sobie wzajemnie różnice zdań, przekonań, a nawet sposobu rozumienia znaczenia pojedynczych słów - są niezbędnym warunkiem poszanowania podmiotowości każdego członka rodziny, a tym samym powstania i istnienia dialogicznej relacji.

\section{O znaczeniu zasad i granic}

Jedną z częstszych trudności związanych z dialogiczną komunikacją w rodzinie, szczególnie między rodzicami a dzieckiem, jest wyznaczanie granic - zasad postępowania. Definiują one to, co dziecku wolno oraz to, co

\footnotetext{
38 Tamże.

39 W. Stern, Allgemeine, s. 105.
} 
jest zabronione. Jak wskazuje M. Pawelec, współcześnie przyjmuje się, że dziecku przysługuje status podmiotu i jednocześnie utożsamia się podmiotowość dziecka z jego równorzędnością osobom dorosłym. W efekcie dyscyplina i dyscyplinowanie traktowane są jako „narzędzia restrykcji i przymusu, sprzeczne z podmiotowym traktowaniem" "40. Utożsamiając dyscyplinę $\mathrm{z}$,ustalaniem sprawiedliwych granic, przekazywaniem zasad postępowania, wydawaniem jasnych, uprzejmych i asertywnych poleceń, udzielaniem pochwał, zachęcaniem do współdziałania i stosowaniem jednolitych konsekwencji niewłaściwego zachowania"41, autorka wskazuje na jej znaczenie dla właściwego rozwoju dziecka, zwłaszcza jego podmiotowości ${ }^{42}$.

Stanowisko to jest zgodne z propozycją W. Sterna. Wskazywał on, że orientacja na konwergentne współdziałanie (osobowy, dialogiczny kontakt) jest właściwa człowiekowi od chwili narodzin, jednak do swojego „wyzwolenia" wymaga kontaktu z otoczeniem innych osób, sprzyjających uwarunkowań. Jednym z nich jest dookreślanie granic, zasad postępowania odpowiadajacych możliwościom osoby - w tym wypadku dziecka. Bez granic, bez zasad dziecko może pozostać na etapie zabezpieczającej status quo, egocentrycznej realizacji siebie, bez otwartości na wymagania (a więc i możliwości) oferowane przez innych ${ }^{43}$.

Granice-zasady można porównać do pewnych dróg, szlaków, po których porusza się dziecko i które ułatwiają mu dokonywanie wyborów między zachowaniami pożądanymi a niepożądanymi. Muszą one być jednak komunikowane w sposób jasny i zrozumiały. Wydaje się to oczywiste - jednak bardzo często tak nie jest. Rodzice często używają zwrotów, które dla dziecka niewiele znaczą: „Bądź grzeczny”, ,Zachowuj się”. Zamiast dotyczyć konkretnych zachowań, skupiają się na postawach, wartościach czy ogólnych przekazach, stając się niejasne i trudne do osiagnięcia ${ }^{44}$. Podobnie jak w przykładzie z rysowaniem kwiatów czy drzew - dziecko może inaczej niż rodzice rozumieć, czym jest grzeczne zachowanie, porządek w pokoju czy dobrze spędzony czas. Rodzice często posługują się formą: „Czy nie widzisz, że" i oczekują, że dziecko samo wyciągnie wniosek, jak ma zachować się, co ma poprawić. Z jednej strony ta forma jest niejasna, ale też zrzuca

${ }^{40}$ M. Pawelec, Rola dyscypliny i dyscyplinowania w rozwoju podmiotowości dziecka. Analiza psychologiczna w świetle literatury przedmiotu, „Horyzonty Psychologii” 1 (2011), s. 79.

41 Tamże.

42 Tamże, s. 79-80.

${ }^{43}$ Por. W. Stern, Allgemeine, s. 105.

${ }^{44}$ J. Sakowska, A. Zajic, M. Talar, M. Witkowska, Jak kochać $i$ wymagać. Poradnik dla rodziców, Warszawa 2011, s. 4-5. 
odpowiedzialność na drugą osobę - na dziecko, które ma przewidzieć, domyślić się, jakie zachowanie jest pożądane ${ }^{45}$.

Ustalanie granic, wprowadzanie zasad postępowania musi jednocześnie obejmować wszystkich członków rodziny. Tylko w ten naturalny sposób dziecko może nauczyć się ich respektowania, bez poczucia krzywdy, przedmiotowego traktowania. Powinny być one również stabilne i wyraźne - aby dawały mu możliwość orientacji, aby ukierunkowywały jego aktywność, ale jednocześnie elastyczne - nie mogą wyznaczać schematów działania niezależnych od konkretnych uwarunkowań. Tylko wówczas mogą spełniać swoją funkcję ${ }^{46}$.

\section{Zakończenie}

Rola komunikacji w rodzinie jest niebagatelna. Komunikacja jest niezbędna, aby poznać członków rodziny, przeciwdziałać konfliktom, a kiedy się pojawią - umiejętnie je rozwiązywać. Dialog zakłada, że uczestniczyć może w nim każdy członek rodziny, na podobnych prawach. Nie oznacza to, że granice między rodzicami a dziećmi mają zaniknąć. Dziecku należy się szacunek - ale od dziecka tego szacunku należy także wymagać. Dzięki rozmowie dziecko może nauczyć się, jakie zasady panują i w rodzinie, i w społeczeństwie.

Stawianie wymagań nie oznacza jednak pozbawienia dziecka jego podmiotowości. Komunikacja między rodzicami a dzieckiem jest kształtowana przez lata - stopniowo. W ciagu tych lat zmieniają się tematy codziennych rozmów, problemy czy trudności, z którymi zmagają się i rodzice, i dziecko. Dziecko, właśnie dzięki rozmowie, uczy się, że może zwrócić się do rodziców $\mathrm{z}$ każdym problemem i że (choć nie jest równorzędnym partnerem) jest traktowane $z$ należnym mu szacunkiem.

Każda forma komunikacji z dzieckiem, jak również każda forma komunikacji między dorosłymi - jako wyraz ich wzajemnego ustosunkowania, jakości ich relacji - jest przedmiotem obserwacji, doświadczeniem dziecka. Będzie istotna dla kształtowania przez to dziecko jego sposobu nawiązywania relacji $z$ innymi, jego sposobu postrzegania siebie $i$ innych $w$ takiej relacji. Dojrzały (a tym samym względnie trwały) sposób komunikacji nie powinien (i w zasadzie nie może) być nabywany w toku szkolenia, treningu etc., na zasadzie mechanicznego powtarzania nawykowych tendencji. Wa-

${ }^{45}$ Por. A. Faber, E. Mazlish, Jak mówić, żeby dzieci nas stuchaty. Jak stuchać, żeby dzieci do nas mówity, Poznań 1992.

${ }^{46}$ M. Pawelec, dz. cyt., s. 82. 
runkiem dojrzałej komunikacji jest dojrzałość osób w nią zaangażowanych. Dojrzałość ta, zgodnie z ujęciem W. Sterna, dookreślana jest w procesie wzajemnych, dialogicznych relacji z drugim człowiekiem. Wyznaczona jest zaufaniem do siebie, własnych możliwości, otwartością na realizację wartości oraz otwartością na drugiego człowieka - jego odmienność, jego niepowtarzalność, na „zakorzeniony w nim” (przyjęty przez niego na podstawie doświadczeń) system jego wartości. Dzięki tej dojrzałości można mówić o osobowym (dialogicznym) spotkaniu dwóch osób.

Dialog, osobowa relacja - nie mechaniczna interakcja przeciwstawnych sobie podmiotów (walczących ze sobą w sposób bardziej lub mniej otwarty) - warunkowane są zatem wzajemnym zaufaniem i poszanowaniem swej podmiotowości. Będą one podstawą budowania trwałych relacji. Mogą być też podstawą trwałości rodziny w sytuacji zmagania się z życiowymi trudnościami. W życiu rodziny (i każdego człowieka) pojawiają się trudne okresy - związane między innymi z utrata pracy, choroba, a nawet wynikające z pewnych prawidłowości rozwojowych (na przykład okres dorastania). W każdej z tych sytuacji mogą pojawić się różnego rodzaju lęki, negatywne emocje oraz inne trudności. Bezosobowe nastawienie (interakcja) zwiększa zagrożenie, że trudne sytuacje przestaną być dla rodziny rodzajem wyzwania, a staną się poważnym zagrożeniem. Rola dialogu - ugruntowanego w dojrzałym stylu działania członków rodziny - może być więc w tym względzie nie do przecenienia.

\section{Communication in the Family: from Interaction to Personal Relationship (a Personalistic Perspective) (Summary)}

The aim of the paper is to present the key issues related to communication in the family from a personalistic perspective. A concept of the character proposed by William Stern served as a inspiration. This perspective varies from the previous ones related to the process of communication, analyzing its structure/course or its effect on human functioning. It does not focus on the process itself or the object of the communication process but on the subject of this process: on the characterological maturity of family members, a maturity that, according to Stern, is the basis of their mutual interrelationship, manifested in action. Character will, therefore, be also manifested in a specific form of communication between family members: immature - interactive - or mature - dialogical, personal relationship. Such a perspective may complement the current ones. It may also prove inspiring for specialists working with the family.

Keywords: communication; character; maturity; family; William Stern. 


\section{Komunikacja w rodzinie: od interakcji do osobowej relacji (perspektywa personalistyczna) (Streszczenie)}

Celem artykułu jest zaprezentowanie podstawowych zagadnień związanych z komunikacją w rodzinie z perspektywy personalistycznej. Inspiracją stała się koncepcja charakteru Williama Sterna. Jest to perspektywa odmienna od dotychczasowych ujęć procesu komunikacji, analizujących jego strukture/przebieg lub też jego wpływ na funkcjonowanie człowieka. Nie koncentruje się ona na samym procesie czy przedmiocie procesu komunikacji, lecz na podmiocie tego procesu - na charakterologicznej dojrzałości członków rodziny. Charakter człowieka (zgodnie ze stanowiskiem Sterna) jest podstawą ustosunkowania człowieka do świata, wyrażanego w działaniu. Przyjmujemy, że charakter będzie wyrażał się również w określonej formie komunikacji członków rodziny: niedojrzałej - interakcyjnej lub też w dojrzałej - dialogicznej, osobowej relacji. Taka perspektywa może dopełnić dotychczasowe ujęcia. Może okazać się również inspirująca dla specjalistów pracujących $\mathrm{z}$ rodzina.

Słowa kluczowe: komunikacja; charakter; dojrzałość; rodzina; Stern William. 